\section{Stakeholder perceptions of chairside teaching and learning in one UK dental school}

\author{
J. Sweet, ${ }^{1}$ L. Pugsley ${ }^{2}$ and J. Wilson ${ }^{3}$
}

VERIFIABLE CPD PAPER
IN BRIEF

- Outlines the views of all those involved in chairside teaching at one dental school.

- Dental undergraduates' and dental nurses' views contrasted with those of dental tutors.

- Dental undergraduates and dental nurses recognise the value of interprofessional education and training for dental tutors.

As a hands-on clinical educational programme, undergraduate dentistry is an anomaly in higher education. This study aimed to evaluate the perceptions of chairside teaching of dental team stakeholders, including dental nurses, dental students and dental tutors at a single UK dental school. From this sample the penetration of current learning and teaching innovations within higher education into the specialist field of clinical dentistry could be evaluated. This article is the first of a series of four which investigates the perceptions of stakeholders of chairside teaching at a single dental school. The second evaluates chairside teaching on a UK wide scale. The third provides educational tools to encourage collaboration and sharing good chairside teaching practice. A further accompanying article reviews some of the educational methodology and innovations in teaching and learning that may be applied to dentistry.

\section{INTRODUCTION}

There have been a remarkable number of innovations in teaching and understanding of student learning in recent years in higher education that may have contributed to a better learning experience for students. These have been discussed in the accompanying education innovation paper in this series.

\section{PERCEPTIONS OF CHAIRSIDE TEACHING}

1. Stakeholder perceptions of chairside teaching and learning in one UK dental school

2. Chairside teaching and the perceptions of dental teachers in the UK

3. Tools to share good chairside teaching practice: a clinical scenario and appreciative questionnaire

4. Educational innovations for dentistry

${ }^{1 * 3}$ Clinical Senior Lecturers, c/o Room 216, Dental School, Cardiff University, Heath Park, Cardiff, CF14 $4 \mathrm{XY} ;{ }^{2}$ Senior Lecturer, Academic Unit of Postgraduate Medical and Dental Education, Wales College of Medicine, Biology, Life \& Health Sciences, Cardiff University, Heath Park, Cardiff, CF14 4XN

*Correspondence to: Mr John Sweet

Email:sweetj@cardiff.ac.uk

\section{Refereed Paper}

Accepted 16 July 2008

DOI: 10.1038/sj.bdj.2008.934

${ }^{\circledR}$ British Dental Journal 2008; 205: 499-503
For the dental student the learning situation is far more complex than most. Acceptable practice in dentistry is a well-defined spectrum of activity delimited by the need for patient safety and to abide by current guidelines in using specialised techniques, equipment and materials. There is little literature on how students from diverse backgrounds adapt and conform to this specific culture of assumed and expected standards. A brief review is carried out in the second paper in this series.

Dental chairside teaching is unique because the student takes responsibility for the restoration and preservation of a patient's oral health under guidance from a tutor. Not only is communication with patients of vital importance to inform and encourage them to engage with disease prevention measures but also some treatment options involve making irreparable changes to structures in the mouth. Successful dental care should therefore include a sensitivity to the wishes of patients as well as technical ability and, most important, an understanding of risk, what to do, when to intervene, and to critically appraise treatment outcomes.

The purpose of this study was to widen the field of investigation to include the perceptions of multiple stakeholders in dental chairside teaching, which has not been reported in the literature so far. As a way forward, a detailed study of a sample of dental students, dental nurses and dental tutors was carried out in one dental school. Different survey methods were selected using the most appropriate for any specific dental team group. These multiple methods had the advantage of providing 'triangulation' as multiple measures ensure that the variance reflected is that of the subject of the research and not that associated with the measures. ${ }^{1}$

\section{METHODOLOGY}

A UK dental school (Cardiff) was selected as a case study for the project and stakeholders sampled to give as wide a representation as possible for their group. Ten dental tutors (out of a possible 35 academic clinical staff) were invited to take part using maximum variety sampling $^{2}$ to represent a range of age and experience, seniority, gender and full or part-time employment. One to one, semi structured qualitative interviews were used $^{3}$ to allow for in depth accounts to be obtained from the teachers (Table 1).

Focus groups were conducted with 24 fourth year dental students out of a cohort of 54 and 12 qualified dental nurses out of cohort of 24, all of whom volunteered in response to an email 
request from the non-dental author. Fourth year dental students were chosen because they had experienced a full year of clinical chairside teaching and were therefore experienced enough to critically appraise what they were experiencing. Fully trained dental nurses were chosen because they were conversant with the training of dental students.

The focus group was chosen as the qualitative research tool since it has the advantage that multiple views could be elicited on the same interview occasion, allowing for the group dynamic to confirm or refute opinions. ${ }^{4}$ Each group consisted of between six and eight participants with the moderator using a schedule designed to allow the participants to explore their attitudes and understanding of dental student learning in the clinic and their response to the teaching they receive. ${ }^{4-5}$ The questioning became progressively more focused in order to stimulate discussions about the topic.

Since in chairside teaching the patient is the teaching model, providing the student with an opportunity to learn practical skills, the patient plays an integral part in the teaching and learning process. A questionnaire was developed and administered to patients following their dental treatment seeking their opinions on teaching and learning. One hundred and fifty questionnaires were distributed to patients, however only $11 \quad(<14 \%)$ were returned. With such a poor return no meaningful results or conclusions could be drawn. It is possible that patients felt unable to comment on the educational experience, or that they were not interested in it, merely attending to receive dental treatment.

\section{DATA ANALYSIS}

The data were collected and, where necessary, transcribed into text and analysed using Atlas.ti software. ${ }^{6}$ As an overview, perceptions were matched against a teaching model, which describes five major approaches. ${ }^{7}$ Detailed analysis of perceptions was then made, point by point, assessing to what degree they appeared 'teacher-centred' or 'student-centred'. ${ }^{8}$

\section{CASE STUDY RESULTS}

Three of the stakeholder groups, the students, the dental nurses and the tutors, engaged enthusiastically with the study.

\begin{tabular}{|c|c|c|}
\hline & Total sample size & Sub-groups \\
\hline DENTAL TUTORS & 10 & INTERVIEWED INDIVIDUALLY \\
\hline $\begin{array}{l}\text { YEAR } 4 \text { DENTAL } \\
\text { UNDERGRADUATES }\end{array}$ & 24 & $\begin{array}{l}4 \text { FOCUS GROUPS EACH WITH } \\
6 \text { STUDENTS }\end{array}$ \\
\hline TRAINED DENTAL NURSES & 8 & $\begin{array}{l}1 \text { FOCUS GROUP WITH } \\
8 \text { STUDENTS }\end{array}$ \\
\hline
\end{tabular}

\begin{tabular}{|c|c|c|}
\hline LEARNING & TEACHER CENTRED & STUDENT CENTRED \\
\hline THROUGH THINKING & Talking lecturing at students & $\begin{array}{l}\text { Teacher listens and structures } \\
\text { student learning }\end{array}$ \\
\hline BY DOING & By demonstration & By doing it themselves \\
\hline $\begin{array}{l}\text { BY STUDENTS } \\
\text { WORKING TOGETHER }\end{array}$ & $\begin{array}{l}\text { Teaching by tutor no } \\
\text { learning together }\end{array}$ & Learning with peers \\
\hline $\begin{array}{l}\text { BY WORKING WITH } \\
\text { DENTAL CARE }\end{array}$ & $\begin{array}{l}\text { Teaching by tutor no learning } \\
\text { with DCPs }\end{array}$ & $\begin{array}{l}\text { Interaction and learning } \\
\text { with DCPs }\end{array}$ \\
\hline $\begin{array}{l}\text { BY RETURNING TO } \\
\text { THOUGHTS AND ACTIONS }\end{array}$ & $\begin{array}{l}\text { Teacher / expert intuits knowledge } \\
\text { Student / novice knows very little } \\
\text { So neither needs to reflect }\end{array}$ & $\begin{array}{l}\text { Reflection essential for an } \\
\text { understanding of skills development }\end{array}$ \\
\hline $\begin{array}{l}\text { BY GOING ABOUT } \\
\text { PRACTICAL TASKS }\end{array}$ & $\begin{array}{l}\text { Show vision of best outcome } \\
\text { Tell student when wrong }\end{array}$ & $\begin{array}{l}\text { Locate example of best outcome } \\
\text { make and celebrate a range of } \\
\text { errors in simulation }\end{array}$ \\
\hline
\end{tabular}

\begin{tabular}{|c|c|c|}
\hline \multicolumn{3}{|c|}{ TEACHING AND CLINIC ORGANISATION } \\
\hline & TEACHER CENTRED & STUDENT CENTRED \\
\hline MANY DIFFERENT STAFF & To provide a good staff student ratio & $\begin{array}{l}\text { Opportunity to gain a range of } \\
\text { experience learning }\end{array}$ \\
\hline $\begin{array}{l}\text { EDUCATIONALLY } \\
\text { TRAINED STAFF }\end{array}$ & Tend to take over and demonstrate & $\begin{array}{l}\text { Understand learning 'explain, } \\
\text { let think, ask' }\end{array}$ \\
\hline $\begin{array}{l}\text { REGULAR ALLOCATION } \\
\text { OF STAFF }\end{array}$ & $\begin{array}{l}\text { Get to know students less } \\
\text { adjustment to new cases }\end{array}$ & $\begin{array}{l}\text { Continuity of treatment planning } \\
\text { more patient centred }\end{array}$ \\
\hline $\begin{array}{l}\text { DEBRIEFING FOLLOWING } \\
\text { CLINICAL WORK }\end{array}$ & $\begin{array}{l}\text { Talk through issues as the } \\
\text { teacher sees it }\end{array}$ & $\begin{array}{l}\text { Allows student to talk and } \\
\text { express feelings and thoughts } \\
\text { about the session }\end{array}$ \\
\hline
\end{tabular}

Most dental tutors looked on their teaching very much from their own position as teacher. They appeared to consider themselves most clearly as subject specialists or experienced practitioners and to think of teaching as a process of passing on knowledge and students learning by receiving it. Alternatively they see themselves as experts showing students how to do things, treating them like apprentices. In essence students need to know what to do and how to do it. In this there was recognition of the value of briefing and debriefing as good practice, for this laid out opportunity to do things well the first time, and how things could be done better still on a future occasion. There was recognition that some students were more adept practically at linking theory with practice, but differences in learning styles were not considered.

\section{Perceptions as teacher-centred or student-centred}

The perceptions of chairside teaching of all stakeholders appeared to centre around two major themes of 'student learning' and 'provision of teaching and clinical organisation'. The origin of these perceptions could be subdivided into those taking a 'student centred' or 'teacher centred' approach. This is 
illustrated with examples in Tables 2 and 3. The focus groups revealed that the students had a very clear idea of what good chairside teaching could be and whilst they had no academic education theoretical background their responses and views could be aligned to a variety of concepts of learning derived by educational theorists (see Table 2 and discussion in paper 1 of this series).

\section{Learning through thinking}

This is illustrated clearly by one example where one student talking about chairside teaching says:

'Each case is different, you may be thinking at first, well it's a filling. But each one is different; each patient is different. So it's really important to have a chance to think about what we have been taught and draw on it, learn from it. You need to think about what you know and how you are going to use that knowledge.'

This is clearly a 'student centred' view. Prior thinking and placing experience into concept maps indicates having a thinking approach where organisation and structure of knowledge is critical for understanding. ${ }^{1}$ Dental tutors also did not refer to learning theorists, but were clearly interested in what they see is the 'thinking' role for chairside teaching: 'you develop a way of talking to a patient and describing to a patient what you are trying to achieve so logically you can use that skill to talk to the students and describe to them what they need to achieve, what the patient requires and so on' which shows that this teacher believes in passing on knowledge from a 'teacher-centred' perspective encouraging students to think about what they are doing.

\section{Learning by doing}

Other students' perceptions of chairside teaching showed a different emphasis saying:

'It's really a way for allowing us to learn by doing. You know, all the stuff that we are told about in lectures and we read about and the phantom head practices, they all come together in these sessions.'

'I learn best when I make mistakes. That way I'm able to see what's what.'
These comments are aligned to experiential learning concepts of 'learning by doing. ${ }^{9}$ This was one of the strongest perceptions of chairside teaching. But it was also conceived as something haphazard and perhaps its success relied on mistakes. As one tutor noted:

'I think they have no idea of what they're doing; pretty inadequate. I think it happens by accident that they learn. Generally I think they learn by making mistakes'.

It was generally considered that they need 'lots of practice', but how much was difficult to decipher. However one tutor made the point that:

'experience does not make one competent; competence must always be linked with the capability of explaining why'.

\section{Learning by students working together}

Another student perception was to do with working with peer groups:

'It's really good when we have the House Officers in clinic. They are just above us and so know what we need to know. They are more of an equal.'

'I like learning from other students, you can listen and learn in pairs and that's really good, really helpful, you feel comfortable with them.'

These views follow those of educationalists who encourage peer tutoring as an aid to learning. ${ }^{10}$ In contrast a number of the dental tutors opposed the idea of different years working together and the one-year teaching another.

\section{Learning by working with other dental care professionals}

The students reported that:

'The senior dental nurses can give very useful little tips, these are really helpful, we can learn a lot from them and hopefully they learn too in these sessions.'

'I wish the nurses did more of the teaching, the experienced ones are brilliant and a lot of them do supervise us in the one clinic at Bayside and that's invaluable.'

This follows concepts of the value of interprofessional education and the effectiveness of learning and working together. ${ }^{11}$ However, many tutors held negative views about integrated learning with dental care professionals (DCPs), thinking that teaching should be by dentally qualified tutors.

\section{Learning by returning to thoughts or actions}

A concept alluded to by dental tutors but not students was that students start as novices and work their way up through beginner, competent and proficient practitioners - finally to expert. ${ }^{12}$ One tutor working at an intuitive level of expert said:

'...inherently my own organised mind is the crucial thing in trying to identify how to structure a course... some people have got a natural talent for organising, quantifying and structuring and communicating and you can't teach it.'

Some tutors were disparaging of reflective practice, clearly perceiving this as neither required for themselves as intuitive experts, nor for students who as beginners:

'have nothing to reflect upon.'

\section{Learning by doing practical tasks}

Psychomotor skill theory was hinted at by a dental tutor with:

'It's quite important to show them the finished product so they know what a cavity should really look like and this has to be in a variety of situations.'

However, despite the mention of the view of the finished product no mention was made of visualisation of sequential steps or a knowledge of the expected range of common errors related to a skill as important for learning. ${ }^{13}$

\section{Teaching and clinic organisation}

Both dental tutors and students were most articulate about issues concerning the provision of teaching and clinical organisation. The main issues are shown in Table 3 indicating how a focus on the teacher or the student can alter the learning outcomes. Some problems could be clearly related to individual teacher differences:

'The problem is, it depends who is supervising the clinic. There is so much variation in the teaching.' 


\section{Educational training in teaching for dental tutors}

Students were extremely vocal about how they thought clinical tutors should be prepared to teach and how teacher training may be of value:

'The GDP tutors and academics chose to teach and so they should have training. It's very obvious that many of them are not trained to teach and then the sessions are often a waste of time.'

'You can tell Mrs Best has been on a teaching course, she is brill [sic]. She explains things, asks what you think and lets you ask questions.'

'Sometimes the feedback is good, they'll ask what you're doing and why, but some tutors they jump in and tell you what to do and that's no help.'

One tutor thought that:

'There can be something to be said for the teacher that they are terrified of!'

\section{Continuity of dental tutor allocation}

Some problems were perceived by students as defects in clinic organisation:

'The treatment plans vary week by week depending on who is in charge. Often there is a mismatch of specialty with the teaching and the teacher.'

Dental tutors were also concerned that clinical chairside teaching needs:

'Organisation - doing the right thing at the right time.'

\section{Debriefing}

Some students noted:

'These can be really useful, when they happen - which is not that often. You have the opportunity to get a breakdown on the clinic and information on the cases. You can consolidate your knowledge if you can prepare for stuff coming up.'

'Having an opportunity to debrief after a clinic is really useful, you can talk through what you have learned, what went well or what was rubbish.'

'I loved the debriefs, but the tutors are often in a rush to leave at the end of clinic.'

Dental tutors were generally in favour of debriefs, but they have been a fairly recent introduction and have not been fully embedded yet. One said:
'At the end of the session it is important to go over what they've done wrong, to debrief things and that should go on throughout the session and on all the time. Important thing is to realise that you've messed up and what you are going to do about it in future, what are you going to do to remedy the situation.'

\section{Student-centred practice}

Some students reported some dental tutor behaviour that obstructed their learning:

'Mr Hyde spends all his time avoiding us, he's in the office drinking coffee.'

'Some tutors disappear before they sign off our lists and we need the signatures for the records. When this happens I either hide the list and pretend it's been misfiled or keep it in my locker and try and catch them the next week, once I did forge the handwriting, I know I shouldn't have done, but I'm the one who'll be in trouble for not signing off. They should stay 'til the end of the session and do the teaching properly.'

But that is not to say there were no good examples of a student-centred approach:

'Everyone is different and if you're doing a practical procedure you get good at it if you do lots of it - you'll find some that don't find it too difficult to do and I can recognise those straight away - and then there's those that need more nurturing and finally those who find it difficult to relate to a practical situation -and it is those who need more teaching, the others just need guidance.'

'I like to encourage more self-created learning and find the evidence base for clinical methods and use of materials - and importance of writing something down at the time about the clinical work for later reflection.'

\section{DISCUSSION}

Despite various curricula modifications and changes, chairside teaching itself appears to have changed very little over the years, relying on dental tutor/dental student relationship with dental nurses having an assumed supportive but rarely formalised role. Dental tutors appeared to be enthusiastic subject specialists or practitioners who were keen to transfer their skills to the students. However, generally they were not particularly student-centred, nor was the need for educational training in how to teach widely expressed. Dental tutors reported that there was scope for improving the chairside learning experience through organising one-to-one relationship master-classes and attention to the use of technology to improve demonstration visibility, so that students "can see what you're doing'. Part-time dental practitioner lecturers perceived that they helped the students see an all important general practice side to things but despite that they were happy to follow 'a party line' on detail of clinical procedures that are taught. Without educational training, eight of the tutors had very wide ranging views on the degree of 'supervision' that students required and how much they should let the student do and when to 'take over' to demonstrate how it should be done. The idea that intimidation would have a positive learning outcome does not seem to fit with any current educational theory.

Media (other than standard radiographs and photographs) were not widely used to illustrate clinical issues or provide resources for debriefing. Students and dental nurses recognised the value of peer and interprofessional education, a view not shared by the majority of tutors. Only the two tutors with formal training in education favoured peer learning and collaborative teaching. This appeared to be based on how they valued the time spent on their postgraduate education courses, where they reported that networking with other colleagues on the course and across disciplines, was as equally important for their development as the taught elements. Obviously there is some confusion in making use of the 'novice to expert' skills sequence model in the far more complex world of clinical practice. A counter intuitive position is arrived at where novices and experts alike appear to gain little from reflection. The problem lies with taking the original driving skills development sequence ${ }^{12}$ and enlarging it inappropriately into a model for competence and professional development. ${ }^{14}$ Some creative ideas were found for gaining continuity from pre-clinical training: bringing students through from 
the phantom head into the clinic with the same dental tutors - but this was seen as a problem for some teachers not willing to 'risk getting away from the safety of phantom head into the clinic'. Good patient selection for improving the resource of types of patients suitable for teaching is seen as a massive organisational problem of critical importance. Also the importance of debriefing alluded to positively by students and tutors follows a pattern in the education literature. ${ }^{15}$

Resources may be drawn together more fruitfully by reorganising dental curricula so that interdisciplinary students such as undergraduate dental, hygienist and therapist students from a number of years work together in collaborative practices, a process which can be summed up as 'vertical podding'. This may be of particular value in overcoming some of the drawbacks of traditional clinic organisation as suggested by Lawton. ${ }^{16}$ By providing a team of student clinicians with differing skills and learning needs, the treatment requirements of patients can be matched more easily. 'Vertical podding' also provides a favourable collaborative learning situation for peer support where a reliance on other members of a group for learning underpins successful learning. ${ }^{17}$

\section{CONCLUSIONS}

Only a few of the innovations sweeping through higher education have reached dental chairside teaching investigated here. In part, it is the complexity of the clinical teaching situation that has kept teaching traditionally as a dental tutor/ dental student one-to-one relationship. However, in keeping with understandings of social and technological change there are many possibilities for chairside teaching to change too. Some of these were reported as early as $1976^{16}$ and some exemplar schools such as Adelaide ${ }^{18}$ have implemented programmes that include comprehensive educational teacher training in a problem-based curriculum. What was evident from this study was the enthusiasm for chairside teaching of most dental tutors but also the complexity of carrying it out. This paper provides a starting point (much as Frank Lawton's in 1976) to draw attention to the current status of chairside teaching. The next stage will be to investigate chairside teaching more widely across the UK in the second article in this series and to develop educational materials to encourage and to share good chairside teaching practice in the third article. A further accompanying article reviews in greater depth some of the educational methodology and innovations in teaching and learning that may be applied to dentistry.

1. Huberman A M, Miles M B. Data management and analysis methods. In Denzin N K, Lincoln Y S (eds) Collecting and interpreting qualitative materials. pp 179-210. Thousand Oaks, California: Sage, 1998.

2. Morse J M. Designing funded qualitative research.
In Denzi N K, Lincoln Y S (eds). Strategies of qualitative inquiry. pp 56-85. Thousand Oaks, California: Sage Publications, 1998.

3. Cohen L, Manion L. Research methods in education, $4^{\text {th }}$ ed. London: Routledge, 1994.

4. Morgan D L. Focus groups as qualitative research. Thousand Oaks, California: Sage, 1997.

5. Krueger R, Casey. Focus Groups: a practical guide for applied research, 3rd ed. Thousand Oaks, California: Sage, 2000.

6. ATLAS.ti: ATLAS.ti knowledge workbench [software]: http://www.atlasti.com/ Accessed 19 January 2005

7. Pratt D D. Five perspectives on teaching in adult and higher education. Malabar, Florida: Krieger Publishing, 1998.

8. Prosser M, Trigwell K. Understanding learning and teaching: the experience in higher education. Buckingham: Open University Press, 1998.

9. Kolb D A. Experiential learning experience as the source of learning and development. Englewood Cliffs: Prentice-Hall, 1984.

10. Vygotsky LS, Cole M, John-Steiner V, Scibner S, Souberman E (eds). Mind in society: the development of higher psychological processes. ASHEERIC Higher Education Report ed. v. 4. Cambridge: Harvard UP, 1978.

11. Barr H. Interprofessional education: today, yesterday and tomorrow. London: LTSN- Centre for Health Sciences and Practice, 2000.

12. Dreyfus H, Dreyfus S. Mind over machine: the power of human intuition and expertise in the era of the computer. Oxford: Basil Blackwell, 1986.

13. Mayberry W E, Requa-Clark B, Feil P H et al. An introduction to problem-based learning. Kansas: University of Missouri-Kansas City, 1993.

14. Chambers D W, Gerrow J D. Manual for developing and formatting competency statements. J Dent Educ 1994; 58: 559-564.

15. Ments M V. Active talk: the effective use of discussion in learning. London: Kogan Page, 1990.

16. Lawton FE. What can be dome to correct deficiencies in the undergraduate course? Int Dent J 1976; 26: 67-72.

17. Johnson D W, Johnson R T. Learning together and alone, 5th ed. Boston: Allyn and Bacon, 1999.

18. Mullins G, Wetherell J, Townsend G, Winning T, Greenwood F. Problem-based learning in dentistry: the Adelaide experience. Adelaide: University of Adelaide, 2001. 